${ }^{21}$ Fraser RC, Clayton DG. The accuracy of age-sex registers, practice medical records and family practitioner committee registers. $\mathcal{f} R$ Coll Gen Pract $1981 ; 31: 410-9$.

22 Warlow CP, Morris PJ. Transient ischemic attacks. New York: Marcel Dekker Inc, 1982 :ix.

${ }^{23}$ Hatano S. Experience from a multicentre stroke register, a preliminary report. Bull WHO 1976;54:541-53.

${ }^{24} \mathrm{Nie} \mathrm{NH}$, Hull $\mathrm{CH}$, Jenkins JG, et al. Statistical package for the social sciences. New York: McGraw Hill, 1975.

${ }^{25}$ Armitage P. Statistical methods in medical research. Oxford: Blackwell Scientific, 1971:114.

${ }^{26}$ Phillips LH, Whisnant JP, Reagan TJ. Sudden death from stroke. Stroke 1977;8:392-5.

${ }^{27}$ Hansen BS, Marquardsen J. Incidence of stroke in Frederiksberg, Denmark. Stroke 1977;8:633-5.

${ }^{28}$ Garraway WM, Akhtar AJ, Smith DL, et al. The triage of stroke rehabilitation. I Epidemiol Community Health 1981 ;35:39-44.

${ }^{29}$ Herman B, Leyten ACM, Luijk JH, et al. Epidemiology of stroke in Tilburg, the Netherlands: the population based stroke incidence register 2 . Incidence, initial clinical picture and three week case fatality. Stroke 1982;13:629-34.

${ }^{30}$ Mohr JP, Caplan LR, Melski JW, et al. The Harvard Cooperative Stroke Registry: a prospective registry. Neurology 1978;28:754-62.

31 Uedo K, Omae T, Hirota Y, et al. Decreasing trend in incidence and mortality from Hisayama residents, Japan. Stroke 1981;12:154-60.

32 Allen CMC. Clinical diagnosis of the acute stroke syndrome. $Q \mathcal{F} \mathrm{Med}$ (in press).

${ }^{33}$ Skriver EB, Olsen TS. Contrast enhancement of cerebral infarcts, incidence and clinical value in different states of cerebral infarction. Neuroradiology $1982 ; 23: 259-65$.

${ }^{34}$ Pullicino C, Kendall BE. Contrast enhancement in ischaemic lesions. Neuroradiology 1980;19:235-9.

${ }^{35}$ Kinkel WR, Jacobs L. Computerized axial transverse tomography in cerebrovascular disease. Neurology 1976;26:924-30.

${ }^{36}$ Bonita R. Suggested criteria for primary subarachnoid haemorrhage. Monica News (WHO Geneva) 1982;1:10.

\title{
Effect on intra-arterial blood pressure of slow release metoprolol combined with placebo or chlorthalidone
}

\author{
H A KIESO, B A GOULD, S MANN, R S HORNUNG, D G ALTMAN, E B RAFTERY
}

\begin{abstract}
Thirty patients with essential hypertension participated in a double blind crossover trial in which they were randomly allocated to treatment with either once daily slow release metoprolol $(200 \mathrm{mg})$ with placebo or once daily slow release metoprolol $(200 \mathrm{mg}$ ) with chlorthalidone (25 $\mathrm{mg}$ ). Ambulatory intra-arterial blood pressure was recorded continuously for 24-48 hours before treatment and two months after each change in regimen. The response of blood pressure and pulse rate to a standard exercise protocol that included supine rest and tilt, isometric, and dynamic bicycle exercise was measured during the same recording periods. Both treatments appreciably reduced blood pressure and pulse rate; mean daytime intra-arterial blood pressure was reduced from $174 / 95 \mathrm{~mm} \mathrm{Hg}$ to $158 / 85 \mathrm{~mm} \mathrm{Hg}$ by metoprolol plus placebo and to $143 / 78 \mathrm{~mm} \mathrm{Hg}$ by metoprolol plus chlorthalidone. This reduction with the combined treatment was significantly greater than with metoprolol and placebo ( $p$ systolic $=0.001, p$ diastolic $=0.004$ ). Mean night time pressures were reduced from $148 / 78 \mathrm{~mm} \mathrm{Hg}$ to $139 / 75 \mathrm{~mm} \mathrm{Hg}$ by metoprolol plus placebo and to 116 / $61 \mathrm{~mm} \mathrm{Hg}$ by metoprolol plus chlorthalidone. Again the reduction in blood pressure was significantly greater with combined treatment $(p<0.001)$ than with metoprolol plus placebo.
\end{abstract}

Once daily slow release metoprolol is effective in controlling blood pressure, but this effect is greatly enhanced by the addition of a diuretic.

\footnotetext{
Department of Cardiology and Divisions of Clinical Sciences and Computing and Statistics, Northwick Park Hospital and Clinical Research Centre, Harrow, Middlesex

H A KIESO, MB, MRCP, research registrar

B A GOULD, MB, MRCP, registrar

$S$ MANN, MA, MRCP, research registrar

R S HORNUNG, $M B$, MRCP, research registrar

D G ALTMAN, BSC, medical statistician

E B RAFTERY, MD, FRCP, consultant cardiologist

Correspondence to: Dr E B Raftery, Northwick Park Hospital, Watford Road, Harrow, Middlesex HA1 3UJ.
}

\section{Introduction}

Metoprolol is a selective beta adrenoreceptor blocking agent ${ }^{1}$ that has been shown to lower the blood pressure during the day and at night and during dynamic exercise but not isometric exercise. ${ }^{2}$ Chlorthalidone is a long acting diuretic closely allied to the thiazides and the results of studies have shown that a combination of metoprolol and chlorthalidone is effective and well tolerated in mild to moderate hypertension. ${ }^{3}$ Once daily dosage with antihypertensive agents is desirable since it improves compliance, ${ }^{4}$ and metoprolol may maintain its hypotensive effect up to 26 hours after the last dose. ${ }^{5}$

We measured the effects of a single daily dose of a slow release formulation of metoprolol combined with either placebo or chlorthalidone to assess the effectiveness of the combination in terms of both absolute reduction of blood pressure and duration of effect. We also measured the effect of both combinations on blood pressure during a standardised exercise protocol.

\section{Patients and methods}

Thirty patients with uncomplicated essential hypertension (seven women, $23 \mathrm{men}$ ), aged from 36 to 65 years (mean 52 years) were recruited from the hypertension clinic. Patients were included if the mean of three blood pressures taken in the outpatient clinic measured by standard indirect techniques (diastolic=Korotkoff phase V) exceeded $160 \mathrm{~mm} \mathrm{Hg}$ systolic or $95 \mathrm{~mm} \mathrm{Hg}$ diastolic or both. The usual contraindications to beta adrenoreceptor blocking drugs and thiazides were observed. We have row undertaken several studies over three periods of intra-arterial monitoring without complications, and an internal audit of our first 1000 cannulations has shown only a few minor complications (unpublished data). We thus feel confident that there is no contraindication to three periods of intra-arterial blood pressure monitoring in a single patient. Informed consent was obtained, and the trial was approved by the hospital ethical committee.

The patients received no antihypertensive treatment for four weeks before the first study and were then randomly allocated to receive slow release metoprolol $200 \mathrm{mg}$ once daily with placebo or slow release metoprolol $200 \mathrm{mg}$ with $25 \mathrm{mg}$ chlorthalidone once daily, the allocation being double blind. Each patient was requested to take the tablets at 0800 and all were followed up in the hypertension clinic. After about eight weeks (range 7-9) the patients were studied a second time. Each was then switched to the alternative regimen for a further eight weeks, when a third study was performed. Each patient was seen at two 
weekly intervals in the hypertension clinic, where blood pressures were measured by trained nurses using standard mercury sphygmomanometers. Side effects, both volunteered and elicited by direct questioning, were recorded and compliance was checked by tablet counting. Concentrations of serum potassium, creatinine, uric acid, and blood urea were measured once before and twice during each period of treatment.

The technique of continuous intra-arterial ambulatory monitoring of blood pressure has been described. ${ }^{6} \mathrm{~A}$ standardised exercise protocol of supine rest, isometric hand grip, and graded bicycle exercise, which has been previously described, ${ }^{7}$ was carried out after insertion of the intra-arterial cannula.

\section{DATA ANALYSIS}

The techniques of analysis of intra-arterial blood pressure data have been described. ${ }^{8} \theta$ The intra-arterial blood pressure was computed for each hour of the day. The hourly differences between the measurements before treatment and those after treatment with metoprolol plus placebo and between the latter and metoprolol plus chlorthalidone were assessed using Student's paired $t$ test (two tailed). Paired $t$ tests were also used for the analysis of clinic pressures and biochemical data. The mean daytime and night time systolic and diastolic pressures from all three intra-arterial studies were analysed by a linear model analysis, which was an extension of the standard analysis for two period crossover trials. ${ }^{10}$

\section{Results}

Of the 30 patients recruited, 24 completed the study (19 men, 5 women). Three withdrew because of side effects and another three declined to be restudied. The data from these 24 patients only are presented in this paper.

\section{PRESSURES MEASURED IN CLINIC}

The mean supine pretreatment blood pressure taken in the clinic was 182 (SE 4.3)/109 (SE 2.1) $\mathrm{mm} \mathrm{Hg}$, falling to 146 (SE 6.6)/89 (SE 3.8) $\mathrm{mm} \mathrm{Hg}$ after metoprolol with placebo and to 136 (SE 5.9)/86 (SE 2.9) $\mathrm{mm} \mathrm{Hg}$ after metoprolol with chlorthalidone. The mean standing pressures were 173 (SE 4.3)/109 (SE 2.1) mm Hg, 146 (SE 6.3)/91 (SE 3.9) $\mathrm{mm} \mathrm{Hg}$, and 135 (SE 5.6)/87 (SE 2.8) $\mathrm{mm} \mathrm{Hg}$ respectively No patient complained of symptoms of postural hypotension. The reductions in pressure after treatment were statistically significant $(\mathrm{p}<0.001)$.

\section{AMBULATORY PRESSURES}

The pretreatment 24 hour curves showed a pattern similar to that reported by our group ${ }^{9}$ (fig 1). Metoprolol plus placebo and metoprolol plus chlorthalidone both caused an appreciable reduction of the blood pressure and heart rate. The mean daytime blood pressure was reduced from $174 / 95 \mathrm{~mm} \mathrm{Hg}$ to $158 / 85 \mathrm{~mm} \mathrm{Hg}$ by metoprolol with placebo and to $143 / 78 \mathrm{~mm} \mathrm{Hg}$ by metoprolol and chlorthalidone. The effect of the active combination was significantly greater than metoprolol with placebo for both systolic $(p=0.001)$ and diastolic pressures $(\mathrm{p}=0.004)$ (table I).

The mean night time pressures were $148 / 78 \mathrm{~mm} \mathrm{Hg}, 139 / 75 \mathrm{~mm} \mathrm{Hg}$, and $116 / 61 \mathrm{~mm} \mathrm{Hg}$ for pretreatment, metoprolol with placebo, and metoprolol with chlorthalidone respectively. The effect of the
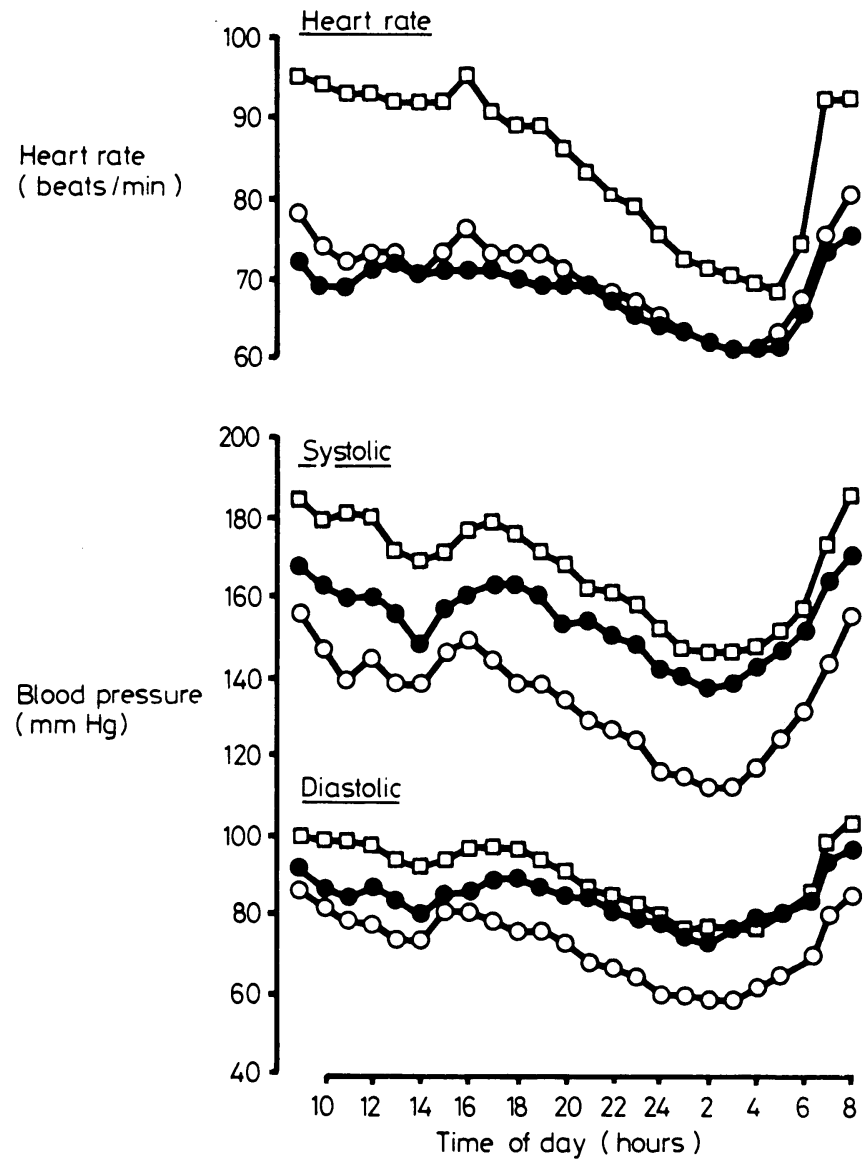

FIG 1 - Twenty four hour circadian curves before treatment $\square-1]$, after metoprolol and placebo - 0 , and after metoprolol and chlorthalidone $\cap-\bigcirc$.

combination of metoprolol and placebo was barely significant for systolic pressure $(p=0.045)$ and not significant $(p=0.35)$ for diastolic pressure. The magnitude of reduction with the combination of metoprolol and chlorthalidone was greater than that for daytime pressures $(\mathrm{p}<0.001)$ when compared with metoprolol and placebo.

In crossover studies it is essential to ensure that there are no important differences in the observed efficacies of the drugs according to the order in which they were taken. The mean daytime and night time pressures were thus each examined for a possible treatment order interaction. None of the four interactions was statistically significant $(\mathrm{p}>0.05)$.

\section{PHYSIOLOGICAL TESTING}

Table II summarises the data for supine rest, tilt, and isometric hand grip and table II and fig 2 the data for bicycle exercise. These data show that there was no postural hypotension with either treatment regimen. Metoprolol plus chlorthalidone had a significantly greater effect $(p<0.01)$ on reducing peaks in blood pressure during isometric hand grip. There was no difference in the effect of the two treatment regimens on dynamic bicycle exercise.

TABLE I-Comparison of the differences in mean daytime and mean night time intra-arterial blood pressure between the three periods of the study

\begin{tabular}{|c|c|c|c|c|c|c|c|c|c|c|}
\hline & \multirow{2}{*}{$\begin{array}{l}\text { Pretreatment } \\
\text { mean }\end{array}$} & \multicolumn{3}{|c|}{$\begin{array}{l}\text { Pretreatment versus } \\
\text { metoprolol and placebo }\end{array}$} & \multicolumn{3}{|c|}{$\begin{array}{l}\text { Pretreatment versus } \\
\text { metoprolol and chlorthalidone }\end{array}$} & \multicolumn{3}{|c|}{$\begin{array}{l}\text { Metoprolol and placebo versus } \\
\text { metoprolol and chlorthalidone }\end{array}$} \\
\hline & & Mean change & $\begin{array}{l}95 \% \text { confidence } \\
\text { interval }\end{array}$ & p & Mean change & $\begin{array}{l}95 \% \text { confidence } \\
\text { interval }\end{array}$ & $\mathrm{p}$ & Mean change & $\begin{array}{c}95 \% \text { confidence } \\
\text { interval }\end{array}$ & p \\
\hline \multicolumn{11}{|c|}{ Daytime } \\
\hline $\begin{array}{l}\text { Systolic } \\
\text { Diastolic }\end{array}$ & $\begin{array}{r}174 \\
95\end{array}$ & $\begin{array}{l}16 \cdot 4 \\
10 \cdot 4\end{array}$ & $\begin{array}{l}7 \cdot 9-24 \cdot 9 \\
5 \cdot 7-15 \cdot 1\end{array}$ & $\begin{array}{r}<0.001 \\
-0.001\end{array}$ & $\begin{array}{l}31 \cdot 0 \\
17 \cdot 6\end{array}$ & $\begin{array}{l}22 \cdot 5-39 \cdot 5 \\
12 \cdot 9-22 \cdot 3\end{array}$ & $\begin{array}{l}<0.001 \\
<0.001\end{array}$ & $\begin{array}{r}14 \cdot 6 \\
7 \cdot 2\end{array}$ & $\begin{array}{l}6 \cdot 1-23 \cdot 1 \\
2 \cdot 5-11 \cdot 9\end{array}$ & $\begin{array}{l}0.001 \\
0.004\end{array}$ \\
\hline \multicolumn{11}{|c|}{ Night time } \\
\hline $\begin{array}{l}\text { Systolic } \\
\text { Diastolic }\end{array}$ & $\begin{array}{r}148 \\
78\end{array}$ & $\begin{array}{l}8.9 \\
2 \cdot 8\end{array}$ & $\begin{array}{r}0 \cdot 2-17 \cdot 6 \\
-3 \cdot 1-8 \cdot 7\end{array}$ & $\begin{array}{l}0.045 \\
0.35\end{array}$ & $\begin{array}{l}32 \cdot 2 \\
17 \cdot 0\end{array}$ & $\begin{array}{l}23 \cdot 5-40 \cdot 9 \\
11 \cdot 1-22 \cdot 9\end{array}$ & $\begin{array}{l}<0.001 \\
<0.001\end{array}$ & $\begin{array}{l}23 \cdot 3 \\
14 \cdot 2\end{array}$ & $\begin{array}{r}14 \cdot 6-32 \cdot 0 \\
8 \cdot 3-20 \cdot 1\end{array}$ & $\begin{array}{r}<0.001 \\
<0.001\end{array}$ \\
\hline
\end{tabular}


BIOCHEMICAL MEASUREMENTS (table III)

There was a significant increase in uric acid from $359 \mu \mathrm{mol} / 1$ $(6 \mathrm{mg} / 100 \mathrm{ml}$ ) (pre-treatment) to $447 \mu \mathrm{mol} / 1(7.5 \mathrm{mg} / 100 \mathrm{ml}$ ) after metoprolol and chlorthalidone $(\mathrm{p}<0.001$ ) (the upper limit for our laboratory $=425 \mu \mathrm{mol} / 1(7 \cdot 1 \mathrm{mg} / 100 \mathrm{ml}))$. The same combination also raised the blood urea from $5.7 \mathrm{mmol} / 1$ to $6.7 \mathrm{mmol} / 1(34-40 \mathrm{mg} / 100 \mathrm{ml})$ $(p<0.01)$ (the upper limit $=6.5 \mathrm{mmol} / 1(40 \mathrm{mg} / 100 \mathrm{ml}))$. The serum potassium concentration was only slightly altered by metoprolol and placebo.

\section{SIDE EFFECTS}

Three patients withdrew from the trial because of side effects. One developed severe dyspepsia while taking metoprolol and placebo; a second developed transient ischaemic attacks while taking metoprolol and chlorthalidone; and a third developed depression and had nightmares while taking metoprolol and chlorthalidone. Of the patients who completed the trial, lethargy (four patients) and cold hands and feet (six patients) were the most frequent complaints. One patient complained of impotence and two of "gritty eyes" without objective evidence of ophthalmic lesions.

\section{Discussion}

The efficacy of metoprolol as an antihypertensive agent (on its own or combined with diuretics) has been shown in several trials,,$^{2}{ }^{5}$ and the half life of its effect on heart rate and blood pressure has been shown to be longer than the plasma elimination half life. ${ }^{1}$ Several studies have suggested that a once daily dose of metoprolol may control the blood pressure over 24 hours. ${ }^{211}$ Diuretics have been clearly shown to enhance the antihypertensive effects of beta adrenoreceptor blocking drugs ${ }^{3}$ and have also been shown to produce a uniform lowering of of hourly mean values of intra-arterial pressure without affecting the shape of the circadian curve. ${ }^{12}$ This study was designed to assess the efficacy of a slow release formulation of metoprolol and to show the effect of adding a thiazide diuretic.

The results of the study show that metoprolol alone effectively lowered the daytime blood pressure but had little effect on blood pressure between 0300 and 0800 . This response is closely similar to that in studies of other beta adrenoreceptor blocking blocking drugs that we have published. ${ }^{13}{ }^{14} \mathrm{We}$ have explained
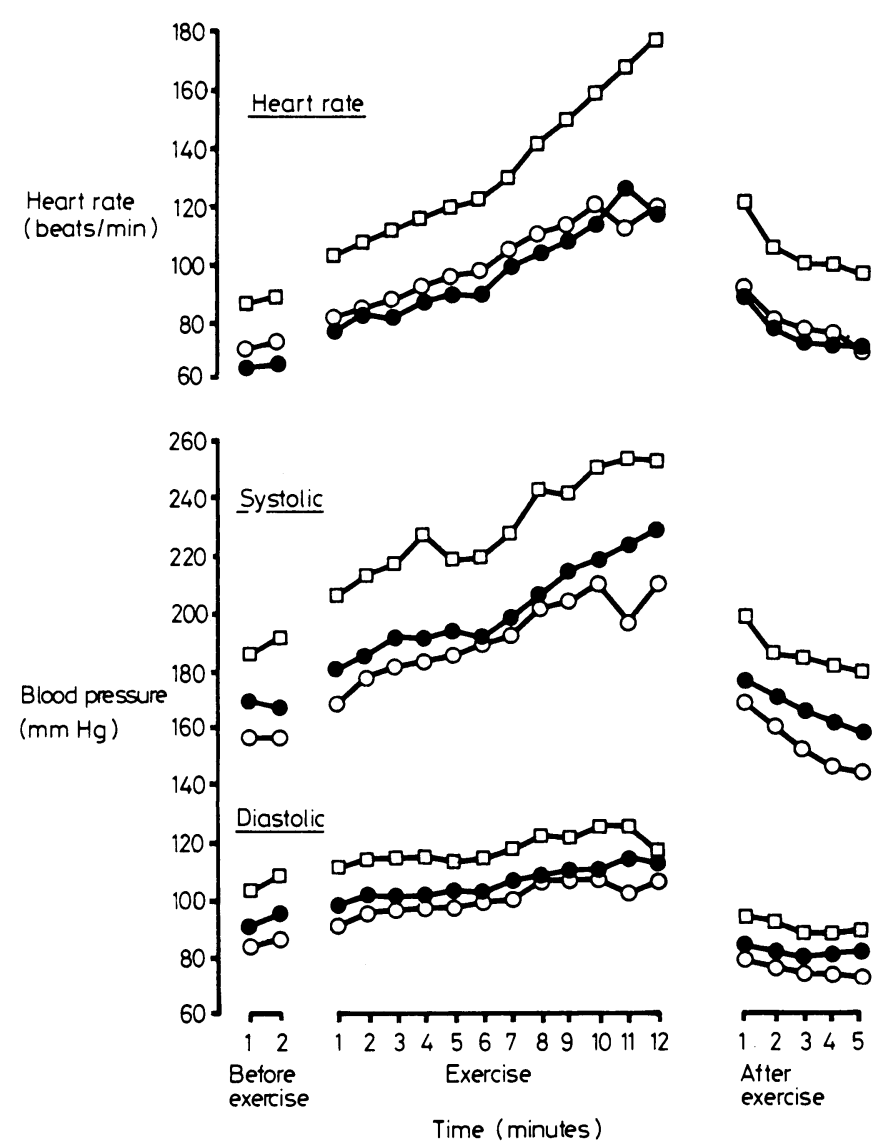

FIG 2-Responses of blood pressure and heart rate to dynamic bicycle exercise before treatment $\square-\square$, after metoprolol plus placebo -0 , and after metoprolol plus chlorthalidone $\mathrm{O}-\mathrm{O}$.

this by postulating that the rise of pressure before awakening is due to intense sympathetic activity mediated at the peripheral arteriole by an alpha receptor. If this is true then beta adrenoreceptor drugs would not be expected to have an effect at this time. The demonstration of an appreciable reduction of the

TABLE II-Mean blood pressures at the end of supine rest, and during tilt, isometric, and dynamic exercise

\begin{tabular}{|c|c|c|c|c|c|c|c|c|c|c|}
\hline & \multicolumn{2}{|c|}{$\begin{array}{c}\text { Mean (SE) blood pressure } \\
\text { before treatment }\end{array}$} & \multicolumn{2}{|c|}{$\begin{array}{l}\text { (B) } \\
\text { Mean blood pressure } \\
\text { on metoprolol } \\
+ \text { placebo }\end{array}$} & \multicolumn{2}{|c|}{$\begin{array}{l}\text { (C) } \\
\text { Mean blood pressure } \\
\text { on metoprolol } \\
+ \text { chlorthalidone }\end{array}$} & \multicolumn{2}{|c|}{$\begin{array}{l}\text { p value } \\
(A v B)\end{array}$} & \multicolumn{2}{|c|}{$\begin{array}{l}\text { p value } \\
(B \cup C)\end{array}$} \\
\hline & Systolic & Diastolic & Systolic & Diastolic & Systolic & Diastolic & Systolic & Diastolic & Systolic & Diastolic \\
\hline $\begin{array}{l}\text { Supine rest } \\
\text { Tilt: }\end{array}$ & $172(6)$ & $91(4)$ & $157(5)$ & $82(3)$ & $141(5)$ & $72(3)$ & $<0.01$ & $<0.02$ & $<0.001$ & $<0.001$ \\
\hline $\begin{array}{c}\text { Minute } 1 \\
\text { Minute } 2 \\
\text { Minute } 3 \\
\text { Minute } 4 \\
\text { Minute } 5 \\
\text { Before isometric } \\
\text { Peak isometric } \\
\text { Bicycle exercise: }\end{array}$ & $\begin{array}{l}167(6) \\
166(5) \\
169(6) \\
169(6) \\
173(6) \\
185(7) \\
219(8)\end{array}$ & $\begin{array}{r}94(4) \\
97(4) \\
98(4) \\
98(4) \\
100(4) \\
91(4) \\
120(6)\end{array}$ & $\begin{array}{l}154(7) \\
151(6) \\
155(7) \\
154(6) \\
154(7) \\
168(6) \\
202(8)\end{array}$ & $\begin{array}{r}85(4) \\
86(4) \\
85(4) \\
85(4) \\
86(4) \\
87(4) \\
108(5)\end{array}$ & $\begin{array}{l}138(5) \\
137(5) \\
134(5) \\
137(5) \\
136(4) \\
154(5) \\
186(8)\end{array}$ & $\begin{array}{l}76(3) \\
76(3) \\
74(3) \\
74(3) \\
75(3) \\
77(3) \\
98(5)\end{array}$ & $\begin{array}{l}<0.05 \\
<0.05 \\
<0.05 \\
<0.05 \\
<0.01 \\
<0.01 \\
<0.02\end{array}$ & $\begin{array}{l}<0.01 \\
<0.01 \\
<0.001 \\
<0.001 \\
<0.01 \\
>0.05 \\
<0.05\end{array}$ & $\begin{array}{l}<0.001 \\
<0.001 \\
<0.001 \\
<0.01 \\
<0.01 \\
<0.001 \\
<0.01\end{array}$ & $\begin{array}{l}<0.001 \\
<0.001 \\
<0.001 \\
<0.001 \\
<0.001 \\
<0.001 \\
<0.01\end{array}$ \\
\hline $\begin{array}{l}\text { Before exercise } \\
\text { 10th minute }\end{array}$ & $\begin{array}{l}191(5) \\
250(9)\end{array}$ & $\begin{array}{l}108(3) \\
125(6)\end{array}$ & $\begin{array}{l}167(7) \\
218(7)\end{array}$ & $\begin{array}{r}95(3) \\
110(5)\end{array}$ & $\begin{array}{l}156(5) \\
209(10)\end{array}$ & $\begin{array}{r}86(3) \\
107(5)\end{array}$ & $\begin{array}{l}>0.05 \\
>0.05\end{array}$ & $\begin{array}{l}<0.01 \\
>0.05\end{array}$ & $\begin{array}{l}<0.001 \\
<0.05\end{array}$ & $\begin{array}{l}<0.001 \\
<0.01\end{array}$ \\
\hline
\end{tabular}

TABLE III-Mean concentrations of blood urea, serum potassium, uric acid, and creatinine before treatment and after each phase of treatment

\begin{tabular}{|c|c|c|c|c|c|}
\hline & $\begin{array}{c}\text { (A) } \\
\text { Mean }+S E \\
\text { before treatment }\end{array}$ & $\begin{array}{l}\text { (B) } \\
\text { Mean on metoprolol } \\
\text { + placebo }\end{array}$ & $\begin{array}{l}\text { (C) } \\
\text { Mean on metoprolol } \\
+ \text { chlorthalidone }\end{array}$ & $\begin{array}{l}\text { p value } \\
v A v B \text { B }\end{array}$ & $\begin{array}{l}\mathrm{p} \text { value } \\
v \mathrm{~A} v \mathrm{C}\end{array}$ \\
\hline $\begin{array}{l}\text { Urea }(\mathrm{mmol} / \mathrm{l}) \\
\text { Creatinine }(\mu \mathrm{mol} / 1) \\
\text { Serum potassium }(\mathrm{mmol}(\mathrm{mEq}) / 1) \\
\text { Uric acid }(\mu \mathrm{mol} / 1)\end{array}$ & $\begin{array}{l}5 \cdot 7(0 \cdot 3) \\
105(9) \\
4 \cdot 2(0 \cdot 1) \\
359(23)\end{array}$ & $\begin{array}{l}6 \cdot 0(0 \cdot 3) \\
109(15) \\
4 \cdot 5(0 \cdot 1) \\
361(18)\end{array}$ & $\begin{array}{r}6 \cdot 7(0 \cdot 4) \\
119(16) \\
4 \cdot 1(0 \cdot 1) \\
447(22)\end{array}$ & $\begin{array}{l}\text { NS } \\
\text { NS } \\
<0.01 \\
\text { NS }\end{array}$ & $\begin{array}{l}<0.001 \\
\text { NS } \\
\text { NS } \\
<0.001\end{array}$ \\
\hline
\end{tabular}

NS $=$ Not significant

Conversion: SI to traditional units-Blood urea: $1 \mathrm{mmol} / 1 \approx 6 \mathrm{mg} / 100 \mathrm{ml}$. Creatinine: $1 \mu \mathrm{mol} / 1 \approx 0.0113 \mathrm{mg} / 100 \mathrm{ml}$. 
mean hourly heart rate curve before awakening clearly indicates that beta adrenoreceptor blockade is still present. Several studies from this laboratory have shown that this part of the circadian curve is reduced by alpha adrenoreceptor blockers, ${ }^{15}$ which again suggests that the alpha receptor is important at this time of the day.

Thiazide diuretics exert their antihypertensive effect by virtue of direct arteriolar vasodilatation, and we have shown that the net effect on the circadian curve is an overall lowering of values without any change in the shape of the curve. ${ }^{12}$ The addition of a diuretic to a beta adrenoreceptor blocking drug would be expected to enhance the daytime effect and also lower the night time and early morning curve. This study shows that this is exactly what happens and suggests that the combination of a beta adrenoreceptor blocker and a diuretic is not only very effective but very desirable.

During isometric exercise metoprolol and placebo caused a reduction in the absolute pressure, and there was an even greater reduction when metoprolol was combined with chlorthalidone. Earlier studies with other beta adrenoceptor blocking agents have shown appreciable reductions of the blood pressure at low grades of dynamic work but not during higher grades. ${ }^{2}$ The results of our study confirm this finding; however, the importance of this is difficult to assess because few patients could achieve the higher workloads.

We have shown that in patients with mild to moderate hypertension slow release metoprolol and placebo produced an appreciable fall in the blood pressure during the daytime only. Metoprolol and chlorthalidone produced an appreciably greater fall in blood pressure which was maintained over the full 24 hours. Both regimens led to a reduction in the response of the blood pressure to isometric and dynamic bicycle exercise. We conclude that adding thiazide diuretics to beta adrenoreceptor blocking drugs enhances the effect and duration of control of blood pressure.

\section{References}

1 Koch-Weser J. Drug therapy; metoprolol. $N$ Engl $\mathcal{f}$ Med 1979;301: 698-703.

${ }^{2}$ Mann S, Millar-Craig MW, Altman DG, Melville DI, Raftery EB. The effects of metoprolol on ambulatory blood pressure. Clin Sci 1979;57, suppl:375-7.

${ }^{3}$ Jaattela A, Pyorala K. A controlled study on the antihypertensive effect of a new beta-adrenergic receptor blocking drug, metoprolol, in combination with chlorthalidone. Br f Clin Pharmacol 1976;3:655-60.

4 Porter A. Drug defaulting in a general practice. Br Med f 1969;i :218-22.

${ }^{5}$ Karlberg B, Nilsson O, Tolagen K, Nitelius E, Waern U. Once daily metoprolol in primary hypertension. Clin Pharmacol Ther $25: 399-407$.

${ }^{6}$ Millar-Craig MW, Hawes D, Whittington J. New system for recording ambulatory blood pressure in man. Med Biol Eng Comput 1978;16: 727-31.

' Gould BA, Mann S, Kieso H, Bala Subramanian V, Raftery EB. The 24 hour ambulatory blood pressure profile with verapamil. Circulation $1982 ; 65: 22-7$.

${ }^{8}$ Cashmann PMM, Stott FD, Millar-Craig MW. Hybrid system for fast data reduction on long term blood pressure recordings. Med Biol Eng Comput $1979 ; 17: 629-35$.

${ }^{9}$ Millar-Craig MW, Bishop C, Raftery EB. Circadian variation of blood pressure. Lancet 1978; i:795-7.

${ }^{10}$ Hills M, Armitage P. The two period cross over clinical trial. $\mathrm{Br} f \mathrm{Clin}$ Pharmacol $1979 ; 8: 7-20$

$"$ Floras J, Fox P, Hassan MO, Jones JV, Sleight P, Turner K. Assessment of the antihypertensive effect of atenolol using 24 hour ambulatory monitoring of the blood pressure. Clin Sci 1979;57, suppl 5:387-9.

12 Raftery EB, Melville DI, Gould B, Mann S, Whittington JR. A study of the antihypertensive actions of xipamide using ambulatory intra-arterial monitoring. Br 7 Clin Pharmacol $1981 ; 12: 381-5$.

${ }^{13}$ Mann S, Millar-Craig MW, Bala Subramanian V, Raftery EB. Once daily beta-blockade in hypertension: an ambulatory assessment. $\mathrm{Br} f \mathrm{Clin}$ Pharmacol $1981 ; 12: 223-8$.

14 Millar-Craig MW, Kenny D, Mann S, Bala Subramanian V, Raftery EB. Effect of once daily atenolol on ambulatory blood pressure. $\mathrm{Br} \mathrm{Med} \mathcal{F}$ $1979 ; \mathrm{i}: 237-9$

15 Gould BA, Mann S, Davies AB, Altman DG, Raftery EB. Alpha-adrenoreceptor blockade with Indoramin in hypertension. $\mathcal{f}$ Cardiovasc Pharmacol 1983;5:343-8.

(Accepted 14 fune 1983)

\title{
Clinical importance of reversibility in primary goitrous hypothyroidism
}

\author{
MOTOTAKA YOSHINARI, KEN OKAMURA, TAKASHI TOKUYAMA, AKIYO SHIROOZU, \\ TOSHIRO NAKASHIMA, KENJIRO INOUE, TERUO OMAE
}

\begin{abstract}
Twenty seven hypothyroid patients with a serum concentration of thyroid stimulating hormone (TSH) of over $40 \mathrm{mU} / 1$ were followed up for three to 20 weeks without replacement therapy. The serum thyroid hormone concentrations increased with a dramatic decrease in serum TSH values in 14 patients (reversible group) but
\end{abstract}

\footnotetext{
Second Department of Internal Medicine, Faculty of Medicine,

Kyushu University, Fukuoka, Japan

MOTOTAKA YOSHINARI, MD, research associate

KEN OKAMURA, MD, staff

TAKASHI TOKUYAMA, MD, research associate

AKIYO SHIROOZU, MD, staff

TOSHIRO NAKASHIMA, MD, senior instructor

KENJIRO INOUE, MD, associate professor

TERUO OMAE, MD, professor
}

Correspondence to: Dr Ken Okamura, Second Department of Internal Medicine, Faculty of Medicine, Kyushu University 60, 3-1-1, Maidashi, Higashi-ku, Fukuoka City 812 , Japan. there was no significant change in the other 13 (irreversible group). Fourteen out of 19 patients with goitre but none of the eight patients without goitre belonged to the reversible group. All of the 11 patients with a high uptake of iodide by the thyroid, three of the six with a normal uptake, and none of the 10 with a low uptake belonged to the reversible group.

These observations indicate that patients with goitrous hypothyroidism with a preserved thyroid uptake of iodide are likely to become euthyroid spontaneously without replacement therapy.

\section{Introduction}

Transient hypothyroidism occurs after delivery ${ }^{1}$ " or after ingestion of excess iodide. ${ }^{3}{ }^{4}$ Hashimoto's thyroiditis is thought to be responsible for this phenomenon. Rallison et al observed spontaneous resolution of hypothyroidism owing to chronic thyroiditis in a large number of school children. ${ }^{5}$ Spontaneous remission of primary hypothyroidism has also been reported 